\title{
Combination Methionine-methylation-axis Blockade: A Novel Approach to Target the Methionine Addiction of Cancer
}

\author{
TAKASHI HIGUCHI ${ }^{1,2,3}$, QINGHONG HAN ${ }^{1}$, NORIHIKO SUGISAWA ${ }^{1,2}$, JUN YAMAMOTO ${ }^{1,2}$, \\ NORIO YAMAMOTO $^{3}$, KATSUHIRO HAYASHI $^{3}$, HIROAKI KIMURA ${ }^{3}$, SHINJI MIWA ${ }^{3}$, KENTARO IGARASHI ${ }^{3}$, \\ MICHAEL BOUVET ${ }^{2}$, SHREE RAM SINGH ${ }^{4}$, HIROYUKI TSUCHIYA ${ }^{3}$ and ROBERT M. HOFFMAN ${ }^{1,2}$ \\ ${ }^{1}$ AntiCancer, Inc., San Diego, CA, U.S.A.; \\ ${ }^{2}$ Department of Surgery, University of California, San Diego, CA, U.S.A.; \\ ${ }^{3}$ Department of Orthopedic Surgery, Kanazawa University, Kanazawa, Japan; \\ ${ }^{4}$ Basic Research Laboratory, National Cancer Institute, Frederick, MD, U.S.A.
}

\begin{abstract}
Background/Aim: Cancers are selectively sensitive to methionine (MET) restriction (MR) due to their addiction to $M E T$ which is overused for elevated methylation reactions. MET addiction of cancer was discovered by us 45 years ago. $M R$ of cancer results in depletion of S-adenosylmethionine (SAM) for transmethylation reactions, resulting in selective cancer-growth arrest in the late $S / G_{2}$-phase of the cell cycle. The aim of the present study was to determine if blockade of the MET-methylation axis is a highly-effective strategy for cancer chemotherapy. Materials and Methods: In the present study, we demonstrated the efficacy of MET-methylation-axis blockade using MR by oral-recombinant methioninase (orMETase) combined with decitabine (DAC), an inhibitor of DNA methylation, and an inhibitor of SAM synthesis, cycloleucine $(C L)$. We determined a proof-of-concept of the efficacy of the MET-methylation-axis blockade on a recalcitrant undifferentiated/unclassified soft-tissue sarcoma (USTS) patient-derived orthotopic xenograft (PDOX) mouse model. Results: The o-rMETase-CL-DAC combination regressed the USTS PDOX with extensive cancer necrosis.
\end{abstract}

This article is freely accessible online.

Correspondence to: Robert M. Hoffman, Ph.D., AntiCancer Inc, 7917 Ostrow St, San Diego, CA, 92111, U.S.A. Tel: +1 6198852284, e-mail: all@anticancer.com; Shree Ram Singh, Ph.D., Basic Research Laboratory, National Cancer Institute, Frederick, MD, U.S.A. Tel: +1 3018467331, e-mail: singhshr@mail.nih.gov; Hiroyuki Tsuchiya, MD, Ph.D., Department of Orthopedic Surgery, Kanazawa University, Kanazawa, Japan. E-mail: tsuchi@med.kanazawa-u.ac.jp

Key Words: Cancer, methionine addiction, methionine restriction, methionine-methylation-axis blockade, decitabine, cycloleucine, MAT2A, soft-tissue sarcoma, PDOX.
Conclusion: The new concept of combination METmethylation-axis blockade is effective and can now be tested on many types of recalcitrant cancer.

Methionine (MET) addiction (1-14) is a fundamental and general hallmark of cancer discovered by us 45 years ago (3). MET addiction is observed in the clinic where the high demand for MET by cancers, results in a strong signal from $\left[{ }^{11} \mathrm{C}\right]-\mathrm{MET}$ PET imaging (2). MET addiction involves elevated MET flux in cancer cells (3-6) due to excess levels of transmethylation reactions (4), known as the Hoffman effect (7). MET addiction is a general phenomenon in cancer and a crucial target for cancer therapy by MET restriction (MR) which results in depletion of free MET and S-adenosylmethionine (SAM) (5, $6,10)$ and selective $S / G_{2}$-phase cell-cycle arrest in cancer cells (11-13). MET addiction is tightly linked to other hallmarks of cancer (14).

Recombinant methioninase (rMETase) targets MET addiction of cancer cells by severely depleting the sources of cellular MET $(1,15)$. We demonstrated the effectiveness of oral administration of rMETase (o-rMETase) on many types of chemotherapy-resistant cancers with patient derived orthotopic xenograft (PDOX) mouse models (15-19).

Decitabine [5-aza-2'-deoxycytidine, (DAC)], which is in clinical use for myelodysplastic syndrome and leukemia treatment, is a DNA-methylation inhibitor that incorporates irreversibly into DNA and causes DNA hypomethylation (20, $21)$. The efficacy of DAC alone for cancer treatment was unsatisfactory (22-26). We recently reported that the combination of o-rMETase and DAC inhibited a recalcitrant undifferentiated/unclassified soft-tissue sarcoma (USTS) PDOX model (27). Cycloleucine (CL), an inhibitor of MET adenosyltransferase-2A (MAT2A), which catalyzes SAM synthesis from MET and ATP, has been shown to lower intracellular SAM (28-30). 


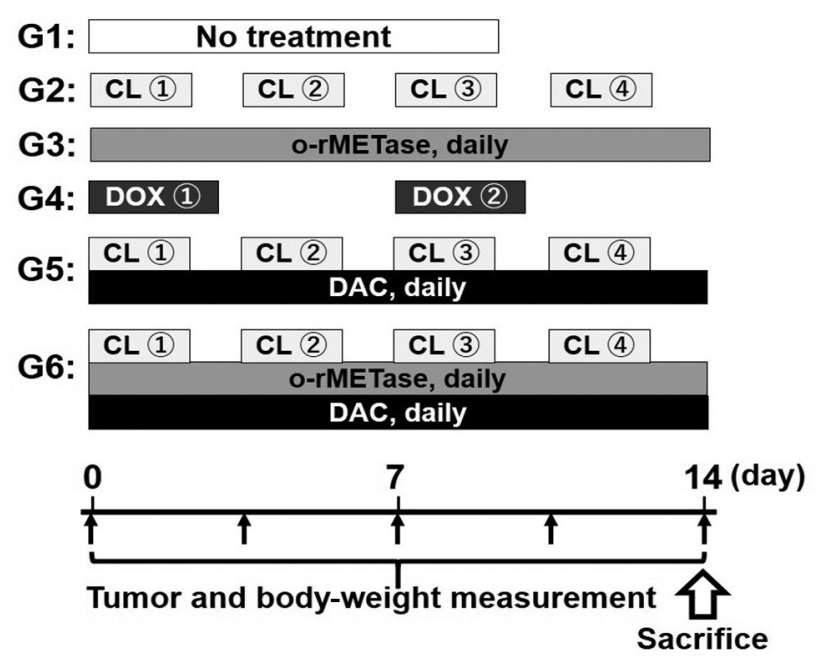

Figure 1. Treatment schema. DOX: Doxorubicin; o-rMETase: oral recombinant methioninase; DAC: decitabine.

Soft-tissue sarcoma is a rare cancer which arises from mesenchymal cells (31). Chemotherapy is used in combination with surgery to treat soft-tissue sarcoma (32). Doxorubicin (DOX) has been used for soft-tissue sarcoma for the past 40 years, but with limited efficacy $(31,33,34)$. USTS, formerly known as malignant fibrous histiocytoma, is a frequent type of soft-tissue sarcoma seen in the middleaged and the elderly (35). The outcome of USTS is usually unsatisfactory when the tumor is resistant to $\operatorname{DOX}(33,34)$.

Based on MET addiction due to excess transmethylation reactions, we hypothesized that CL could be combined with o-rMETase and DAC for MET and methylation blockade for highly effective therapy of the USTS PDOX model. The present report is a proof-of-concept that MET-methylationaxis blockade can effectively target a recalcitrant cancer.

\section{Materials and Methods}

Mice. Athymic nude mice, at 4-6 weeks of age, were from AntiCancer Inc. (San Diego, CA, USA). An IACUC protocol was approved for the present study following the principles and procedures described in the National Institutes of Health Guide for the Care and Use of Animals under Assurance Number A3873-1 (36). All surgical procedures were conducted under appropriate anesthesia and analgesia (36).

Patient-derived tumor. A fresh surgical sample from the USTS patient not otherwise specified (NOS), who underwent surgery at UCLA, was previously brought to AntiCancer, Inc. for establishment in nude mice (34). The patient provided written informed consent with UCLA IRB\#10-001857 approval (34).

Surgical orthotopic implantation (SOI). A single tumor fragment (2$3 \mathrm{~mm}$ ), harvested from a subcutaneously-grown tumor in nude mice, was implanted into the nude-mouse biceps, to establish USTS PDOX models, as described in our previous reports $(27,31)$.
Treatment protocols. The PDOX mouse models (n=6/group) were treated as follows (Figure 1): G1, Untreated control; G2, CL (50 mg/kg, intraperitoneal injection, twice per week); G3, o-rMETase (50 units/mouse, oral gavage, twice per day); G4, DOX (3 mg/kg, intraperitoneal injection, once per week); G5, CL+ DAC $(50 \mathrm{mg} / \mathrm{kg}$, intraperitoneal injection, once per day) ; G6, o-rMETase + CL + DAC. Treatment was initiated after all tumors reached at least $100 \mathrm{~mm}^{3}$. Tumor volume and mouse body weight were measured twice per week.

Histological analysis. The procedures for fixation, sectioning, deparaffinizing, and staining of harvested tumor samples were conducted as described previously (37).

Statistical analysis. Data are presented as mean \pm standard error of the mean (SEM). One-way ANOVA with Tukey's range test and the Student's paired $t$-test were used for statistical analyses.

\section{Results}

MET-methylation-axis blockade regressed the sarcoma $P D O X$. Only the MET-methylation-axis blockade regressed the recalcitrant USTS PDOX tumor $(\mathrm{p}<0.001)$. o-rMETase alone ( $p=0.03)$, the CL-DAC combination $(p=0.003)$, as well as the rMETase-CL-DAC combination MET-methylationaxis blockade $(p<0.001)$ significantly inhibited the USTS PDOX tumor compared to the control. The o-rMETase-CLDAC combination had significantly better efficacy than the other treatments: $v s$. CL alone $(p=0.001)$; vs. o-rMETase alone $(p=0.007)$; or $v s$. DOX alone $(p=0.03)$. CL alone did not inhibit the tumor $(p=0.44)$ (Figures 2 and 3 ).

The combination MET-methylation-axis blockade caused extensive necrosis in the sarcoma PDOX. Only the PDOX tumors treated with the MET-methylation-axis blockade had extensive tumor necrosis. The control USTS PDOX tumor had a high cell density comprising atypical spindle-shaped cancer cells (Figure 4A, A'). USTS PDOX tumors treated with CL alone (Figure 4B, B'), o-rMETase alone (Figure 4C, C'), DOX alone (Figure 4D, D'), and the CL-DAC (Figure 4E, E') combination showed viable pleomorphic cancer cells; however these groups had less viable cancer cells than the untreated control. The o-rMETase-CL-DAC combination induced widespread necrosis (Figure 4F) with non-viable cancer cells and stroma replaced by degenerative scars (Figure 4F'). These results further showed the efficacy of MET-methylation-axis blockade.

Effect of treatment on body weight. Only treatments containing CL caused body-weight loss: CL alone ( $p=0.001)$, the CL-DAC combination $(p=0.001)$, and the o-rMETaseCL-DAC combination $(p=0.001)$ (Figure 5).

\section{Discussion}

MET addiction of cancer is due to excess and aberrant transmethylation reactions, that consume much larger than 

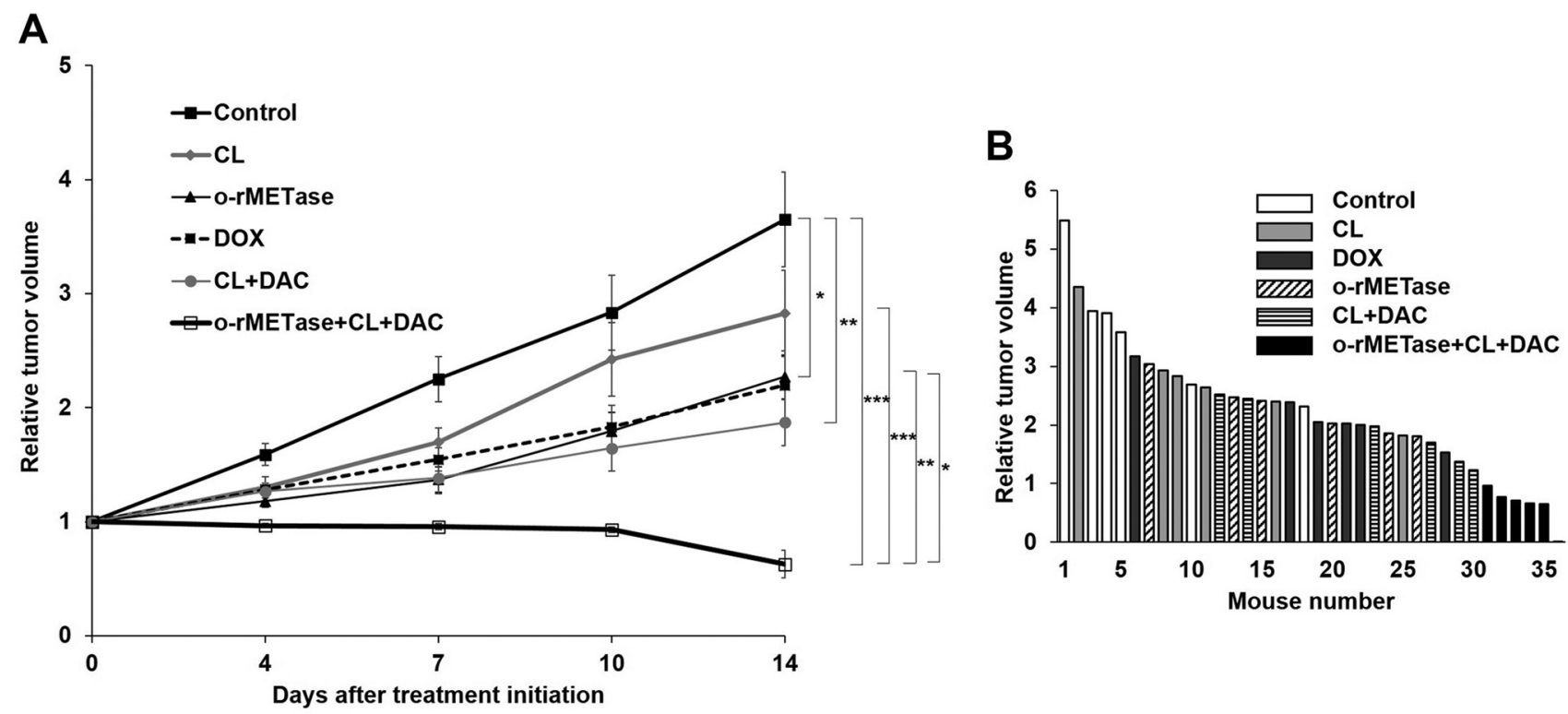

Figure 2. (A) Relative tumor volume of the USTS-PDOX model. (B)Waterfall plot of relative tumor volume. Six mice were in each group. * $p=0.05$; ${ }^{* *} p=0.01 ; * * * p=0.001$. Error bars: \pm SEM. USTS, Undifferentiated/unclassified soft-tissue sarcoma; PDOX, patient-derived orthotopic xenograft; o-rMETase, oral recombinant methioninase; CL, cycloleucine; DOX, doxorubicin; DAC, decitabine; SEM, standard error of the mean .
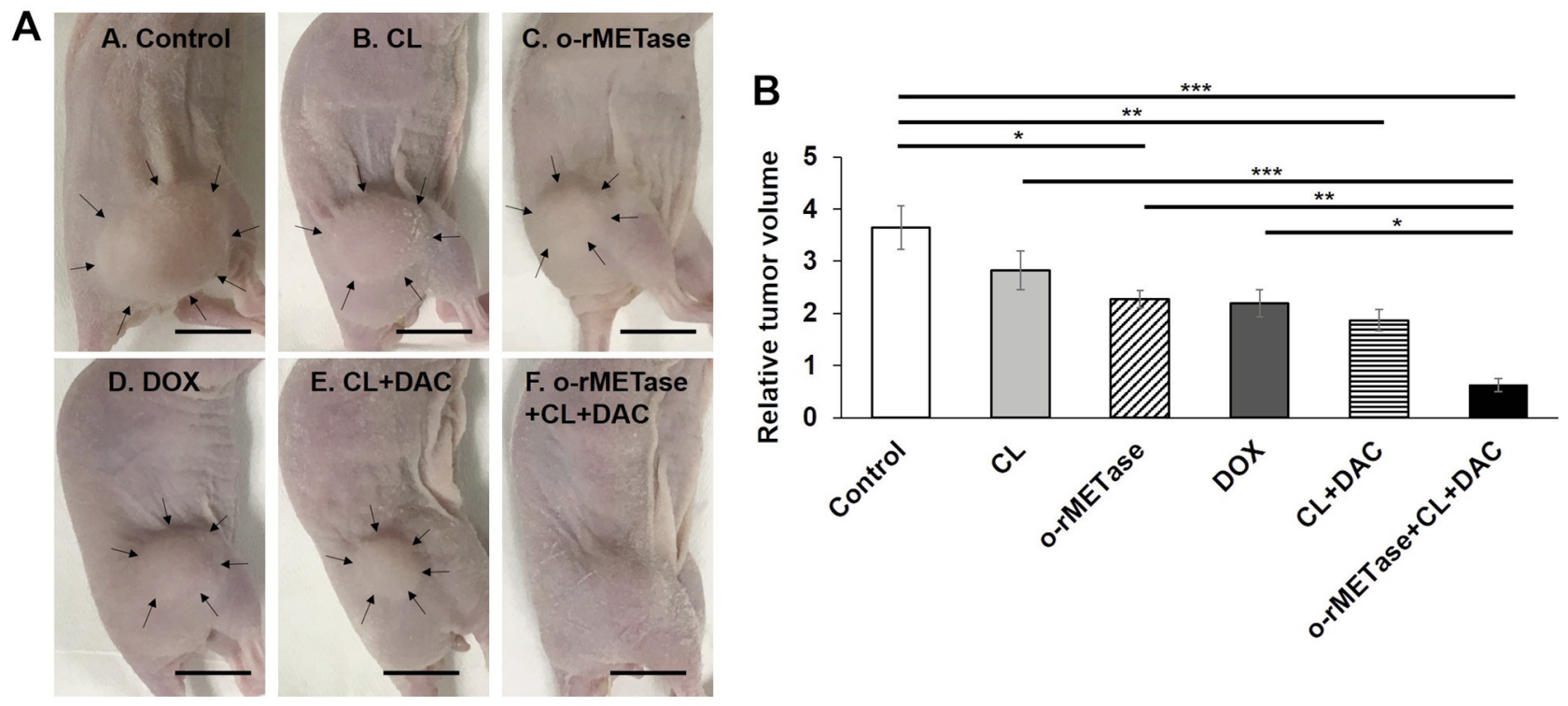

Figure 3. (A) Representative photographs of treated USTS PDOX mouse models on day 14. Arrows show the margin of the tumors. (B) Bar graphs indicate relative tumor volume of each group on day 14. Scale bars: $10 \mathrm{~mm} .6$ mice were in each group. $*_{p}=0.05 ; * * p=0.01 ; * * * p=0.001$. Error bars: \pm SEM. USTS, Undifferentiated/unclassified soft-tissue sarcoma; PDOX, patient-derived orthotopic xenograft; o-rMETase, oral recombinant methioninase; CL, cycloleucine; DOX, doxorubicin; DAC, decitabine; SEM, standard error of the mean.

normal amounts of MET $(3-6,10)$. Lowered DNA methylation is a hallmark of cancer cells, originally discovered in our laboratory (39), and may be due to diversion of methyl groups to other substances such as histones (please see below). Several demethylating agents have been used for cancer treatment $(21,40)$ including DAC, as well as azacitidine which has been used to treat myelodysplastic syndrome (41). These inhibitors cause hypomethylation of DNA, but had limited efficacy in the clinic $(25,40,41)$. In our recent study, a DNA hypomethylating drug alone did not inhibit a USTS- 

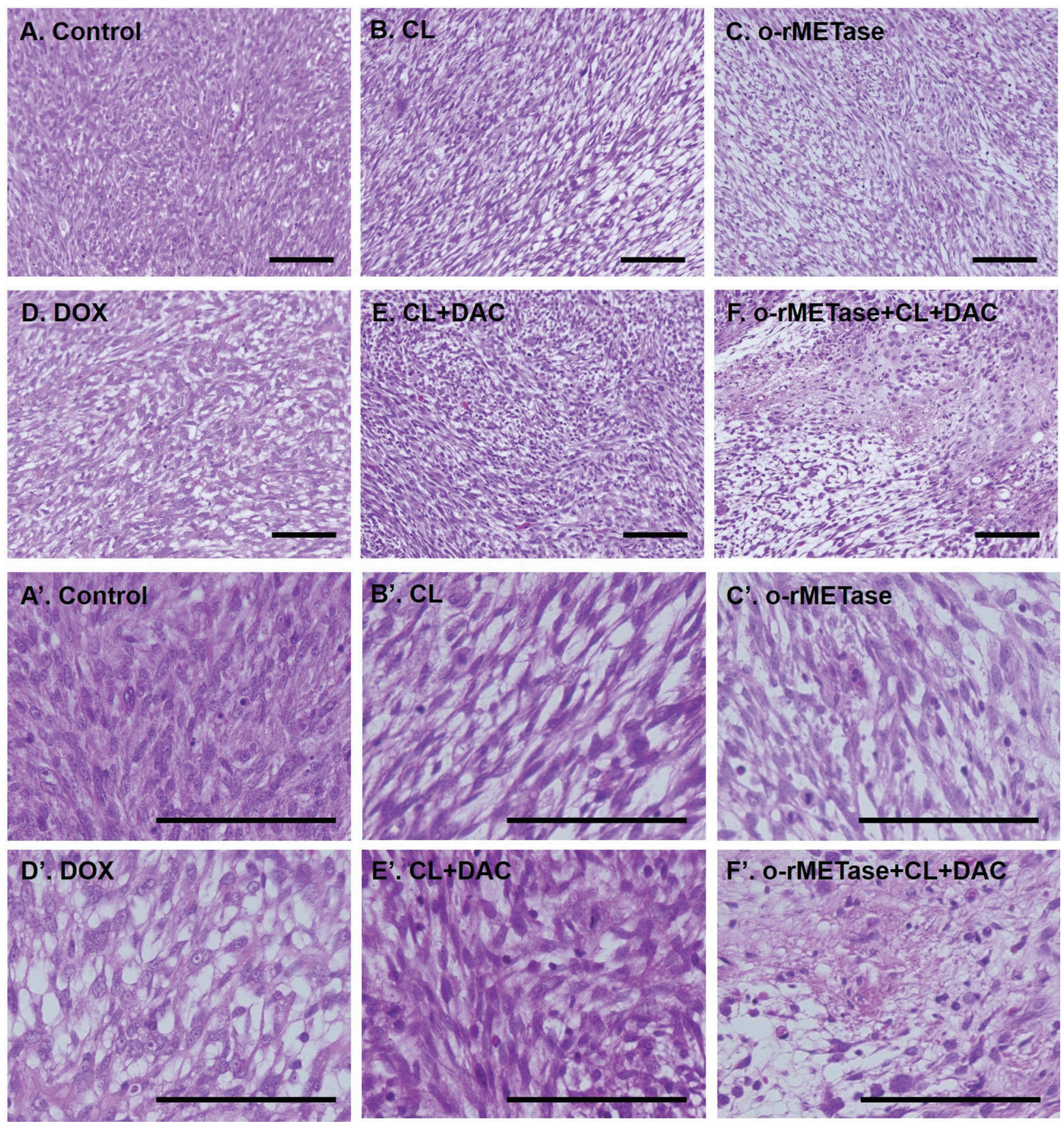

Figure 4. $H \& E$ staining. ( $\left.A, A^{\prime}\right)$ Control. $\left(B, B^{\prime}\right) C L$ alone. $\left(C, C^{\prime}\right)$ o-rMETase alone. ( $\left.D, D^{\prime}\right)$ DOX alone. (E, E') $C L+D A C .\left(F, F^{\prime}\right)$ o-rMETase $+C L+D A C$. Scale bars: $100 \mu \mathrm{m}$. o-rMETase, oral recombinant methioninase; DOX, doxorubicin; CL, cycloleucine; DAC, decitabine.

PDOX, but o-rMETase combined with a DNAhypomethylating drug arrested the PDOX tumors and decreased the cancer-cell density, suggesting the combination of rMETase and a DNA hypomethylating agent could be effective to inhibit tumor growth $(27,37)$.
In order to enhance MR, we examined the efficacy of the SAM-synthesis inhibitor, CL (30) along with o-rMETase and DAC in the present study. SAM, which plays an important role in transmethylation reactions in all cells, is synthesized from MET by MAT2A (28). CL inhibits SAM synthesis by inhibiting 


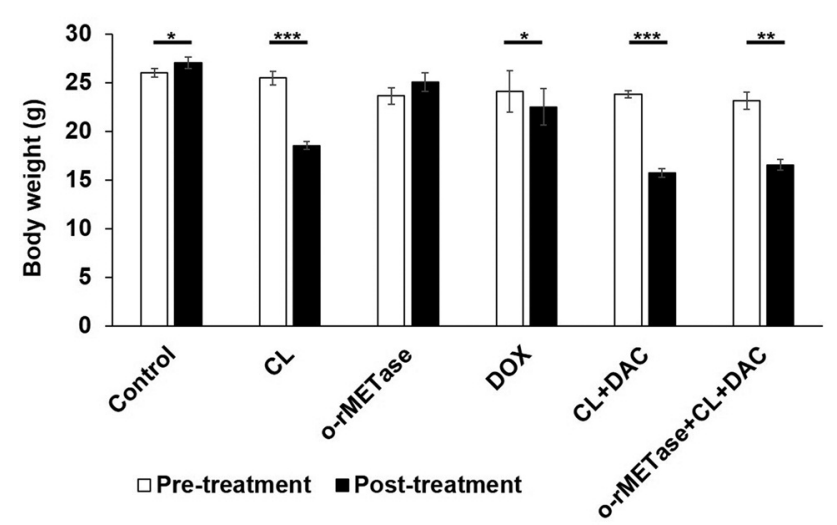

Figure 5. Mouse body-weight. ${ }^{*} p=0.05 ; * * p=0.01 ; * * * p=0.001$. Error bars: \pm SEM. o-rMETase, oral recombinant methioninase; CL, cycloleucine; DOX, doxorubicin; DAC, decitabine; SEM, standard error of the mean.

MAT2A, resulting in hypomethylation in the tumor and may increase the DNA hypomethylation efficacy of DAC $(28,30)$.

CL may be too toxic at the current dose, leading to mouse body-weight loss. Future studies will examine the most effective non-toxic dose of CL for optimal MET-methylationaxis blockade.

o-rMETase has now shown clinical efficacy in a pilot study (42). Recently, a study showing efficacy of a human enzyme engineered to be a METase was published, stating it is superior to the bacterial METase used in the present study, due to its long half-life in the circulation (43). However due to the hardiness of the bacterial enzyme to survive stomach acidity, it could be dosed orally as shown in the present and previous studies $(15-19,27,37)$, giving it superiority over the injected engineered human METase. Bacterial o-rMETase is much superior to injected bacterial rMETase (44). Future studies will include determination of the efficacy of MET-methylation-axis blockade on the major cancer types in PDOX models. Recent papers have come out claiming novelty on MET addiction (45, 46), about which we published long ago (2-12, 47-50). Targeting a central aspect of metabolism such as MET and methylation has far more potential for cancer therapy than targeting peripheral metabolism, despite claims of "metabolic dependence" (51). MET addiction, discovered by us, is found in all cancer types and is linked to other hallmarks of cancer (14). All cancer types tested are sensitive to MR, whether by methionine-free media $(8,52)$, diet $(47-49)$ or methioninase $(15-19,27,37)$. A recent study in our laboratory (53) has demonstrated that the combination of o-rMETase, CL and azacytidine arrested a pancreatic cancer PDOX, further demonstrating that blocking the MET-methylation-axis is highly-effective chemotherapy against recalcitrant cancers and has clinical potential. Other recent studies from our laboratory have shown that excess transmethylation that causes MET addiction in cancer cells results in hypermethylation of histone H3 lysine marks $(54,55)$. These facts suggest MET addiction may be the very basis of cancer (3). Orthotopic mouse models of sarcoma (31) such as that used in the present study, are clinically relevant, unlike ectopic subcutaneous sarcoma mouse models (56). Recently, more potent inhibitors of MAT2A, which is regulated differently in normal and cancer cells (50), have been developed (57) and may be used in METtransmethylation-axis blockade, which directly targets the elevated flux of methionine in cancer cells, termed the Hoffman effect (58).

\section{Conflicts of Interest}

The Authors declare no competing interests.

\section{Authors' Contributions}

Conception and design: TH and RMH. Acquisition of data: TH, QH, NS, JY, NY, KH, HK, SM, and KI. Analysis and interpretation of data: TH, NY, KH, HK, SM, MB, HT, and RMH. Writing, review, and/or revision of the manuscript: TH, HT, SRS, and RMH.

\section{Acknowledgements}

This paper is dedicated to the memory of AR Moossa, MD, Sun Lee, MD, Professor Jiaxi Li, and Masaki Kitajima, MD.

\section{References}

1 Hoffman RM: Development of recombinant methioninase to target the general cancer-specific metabolic defect of methionine dependence: a 40-year odyssey. Expert Opin Biol Ther 15(1): 2131, 2015. PMID: 25439528. DOI: 10.1517/14712598.2015.963050

2 Aki T, Nakayama N, Yonezawa S, Takenaka S, Miwa K, Asano Y, Shinoda J, Yano H and Iwama T: Evaluation of brain tumors using dynamic 11C-methionine-PET. J Neurooncol 109(1): 115122, 2012. PMID: 22528799. DOI: 10.1007/s11060-012-0873-9

3 Hoffman RM and Erbe RW: High in vivo rates of methionine biosynthesis in transformed human and malignant rat cells auxotrophic for methionine. Proc Natl Acad Sci USA 73(5): 1523-1527, 1976. PMID: 179090. DOI: 10.1073/pnas.73.5.1523

4 Stern PH and Hoffman RM: Elevated overall rates of transmethylation in cell lines from diverse human tumors. In Vitro 20(8): 663-670, 1984. PMID: 6500606. DOI: 10.1007/BF02619617

5 Coalson DW, Mecham JO, Stern PH and Hoffman RM: Reduced availability of endogenously synthesized methionine for Sadenosylmethionine formation in methionine-dependent cancer cells. Proc Natl Acad Sci USA 79(14): 4248-4251, 1982. PMID: 6289297. DOI: 10.1073/pnas.79.14.4248

6 Stern PH, Wallace CD and Hoffman RM: Altered methionine metabolism occurs in all members of a set of diverse human tumor cell lines. J Cell Physiol 119(1): 29-34, 1984. PMID: 6707100. DOI: $10.1002 /$ jcp. 1041190106

7 Kaiser P: Methionine dependence of cancer. Biomolecules 10(4): 568, 2020. PMID: 32276408. DOI: 10.3390/biom 10040568 
8 Mecham JO, Rowitch D, Wallace CD, Stern PH and Hoffman RM: The metabolic defect of methionine dependence occurs frequently in human tumor cell lines. Biochem Biophys Res Commun 117(2): 429-434, 1983. PMID: 6661235. DOI: 10.1016/0006-291x(83)91218-4

9 Tan Y, Xu M and Hoffman RM: Broad selective efficacy of recombinant methioninase and polyethylene glycol-modified recombinant methioninase on cancer cells in vitro. Anticancer Res 30(4):1041-1046, 2010. PMID: 20530407.

10 Stern PH, Mecham JO, Wallace CD and Hoffman RM: Reduced free-methionine in methionine-dependent SV40-transformed human fibroblasts synthesizing apparently normal amounts of methionine. J Cell Physiol 117(1): 9-14, 1983. PMID: 6311851. DOI: $10.1002 /$ jcp. 1041170103

11 Hoffman RM and Jacobsen SJ: Reversible growth arrest in simian virus 40-transformed human fibroblasts. Proc Natl Acad Sci USA 77(12): 7306-7310, 1980. PMID: 6311851. DOI: 10.1073/pnas.77.12.7306

12 Yano S, Li S, Han Q, Tan Y, Bouvet M, Fujiwara T and Hoffman RM: Selective methioninase-induced trap of cancer cells in S/G2 phase visualized by FUCCI imaging confers chemosensitivity. Oncotarget 5(18): 8729-8736, 2014. PMID: 25238266. DOI: 10.18632 /oncotarget.2369

13 Guo H, Lishko VK, Herrera H, Groce A, Kubota T and Hoffman RM: Therapeutic tumor-specific cell cycle block induced by methionine starvation in vivo. Cancer Res 53(23): 5676-5679, 1993. PMID: 8242623.

14 Hoffman RM, Jacobsen SJ and Erbe RW: Reversion to methionine independence in simian virus 40-transformed human and malignant rat fibroblasts is associated with altered ploidy and altered properties of transformation. Proc Natl Acad Sci USA 76(3): 13131317, 1979. PMID: 220612. DOI: 10.1073/pnas.76.3.1313.

15 Kawaguchi K, Han Q, Li S, Tan Y, Igarashi K, Murakami T, Unno $M$ and Hoffman RM: Efficacy of recombinant methioninase (rMETase) on recalcitrant cancer patient-derived orthotopic xenograft (PDOX) mouse models: A review. Cells 8(5): 410, 2019. PMID: 31052611. DOI: 10.3390/cells 8050410

16 Higuchi T, Kawaguchi K, Miyake K, Han Q, Tan Y, Oshiro H, Sugisawa N, Zhang Z, Razmjooei S, Yamamoto N, Hayashi K, Kimura H, Miwa S, Igarashi K, Chawla SP, Singh AS, Eilber FC, Singh SR, Tsuchiya H and Hoffman RM: Oral recombinant methioninase combined with caffeine and doxorubicin induced regression of a doxorubicin-resistant synovial sarcoma in a PDOX mouse model. Anticancer Res 38(10): 5639-5644, 2018. PMID: 30275182. DOI: 10.21873/anticanres.12899

17 Igarashi K, Kawaguchi K, Kiyuna T, Miyake K, Miyaki M, Yamamoto N, Hayashi K, Kimura H, Miwa S, Higuchi T, Singh AS, Chmielowski B, Nelson SD, Russell TA, Eckardt MA, Dry SM, Li Y, Singh SR, Chawla SP, Eilber FC, Tsuchiya H and Hoffman RM: Metabolic targeting with recombinant methioninase combined with palbociclib regresses a doxorubicin-resistant dedifferentiated liposarcoma. Biochem Biophys Res Commun 506(4): 912-917, 2018. PMID: 30392912. DOI: 10.1016/j.bbrc.2018.10.119

18 Kawaguchi K, Miyake K, Han Q, Li S, Tan Y, Igarashi K, Kiyuna T, Miyake M, Higuchi T, Oshiro H, Zhang Z, Razmjooei S, Wangsiricharoen S, Bouvet M, Singh SR, Unno M and Hoffman RM: Oral recombinant methioninase (o-rMETase) is superior to injectable rMETase and overcomes acquired gemcitabine resistance in pancreatic cancer. Cancer Lett 432: 251-259, 2018. PMID: 29928962. DOI: $10.1016 /$ j.canlet.2018.06.016
19 Miyake K, Kiyuna T, Li S, Han Q, Tan Y, Zhao M, Razmjooei S, Barangi M, Wangsiricharoen S, Murakami T, Singh AS, Li Y, Nelson SD, Eilber FC, Bouvet M, Hiroshima Y, Chishima T, Matsuyama R, Singh SR, EnDOI and Hoffman RM: Combining tumor-selective bacterial therapy with Salmonella typhimurium A1-R and cancer metabolism targeting with oral recombinant methioninase regressed an Ewing's sarcoma in a patient-derived orthotopic xenograft model. Chemotherapy 63(5): 278-283, 2018. PMID: 30673664. DOI: $10.1159 / 000495574$

20 Sato T, Issa JJ and Kropf P: DNA hypomethylating drugs in cancer therapy. Cold Spring Harb Perspect Med 7(5): a026948, 2017. PMID: 28159832. DOI: 10.1101/cshperspect.a026948

21 Duchmann $M$ and Itzykson R: Clinical update on hypomethylating agents. Int J Hematol 110(2): 161-169, 2019. PMID: 31020568. DOI: 10.1007/s12185-019-02651-9

22 Gailhouste L, Liew LC, Hatada I, Nakagama H and Ochiya T: Epigenetic reprogramming using 5-azacytidine promotes an anticancer response in pancreatic adenocarcinoma cells. Cell Death Dis 9(5): 468, 2018. PMID: 29700299. DOI: 10.1038/s41419018-0487-z

23 Wang X, Chen E, Yang X, Wang Y, Quan Z, Wu X and Luo C: 5 -azacytidine inhibits the proliferation of bladder cancer cells via reversal of the aberrant hypermethylation of the hepaCAM gene. Oncol Rep 35(3): 1375-1384, 2016. PMID: 26677113. DOI: 10.3892 /or.2015.4492

24 Kratzsch T, Kuhn SA, Joedicke A, Hanisch UK, Vajkoczy P, Hoffmann J and Fichtner I: Treatment with 5-azacitidine delay growth of glioblastoma xenografts: a potential new treatment approach for glioblastomas. J Cancer Res Clin Oncol 144(5): 809819, 2018. PMID: 29427211. DOI: 10.1007/s00432-018-2600-1

25 Connolly RM, Li H, Jankowitz RC, Zhang Z, Rudek MA, Jeter SC, Slater SA, Powers P, Wolff AC, Fetting JH, Brufsky A, Piekarz R, Ahuja N, Laird PW, Shen H, Weisenberger DJ, Cope L, Herman JG, Somlo G, Garcia AA, Jones PA, Baylin SB, Davidson NE, Zahnow CA and Stearns V: Combination epigenetic therapy in advanced breast cancer with 5-Azacitidine and entinostat: A Phase II National Cancer Institute/Stand Up to cancer study. Clin Cancer Res 23(11): 2691-2701, 2017. PMID: 27979916. DOI: 10.1158/1078-0432.CCR-16-1729

26 Festuccia C, Gravina GL, D'Alessandro AM, Muzi P, Millimaggi D, Dolo V , Ricevuto E, Vicentini C and Bologna M: Azacitidine improves antitumor effects of docetaxel and cisplatin in aggressive prostate cancer models. Endocr Relat Cancer 16(2): 401-413, 2009. PMID: 19153211. DOI: 10.1677/ERC-08-0130

27 Higuchi T, Han Q, Miyake K, Oshiro H, Sugisawa N, Tan Y, Yamamoto N, Hayashi K, Kimura H, Miwa S, Igarashi K, Bouvet M, Singh SR, Tsuchiya $\mathrm{H}$ and Hoffman RM: Combination of oral recombinant methioninase and decitabine arrests a chemotherapy-resistant undifferentiated soft-tissue sarcoma patient-derived orthotopic xenograft mouse model. Biochem Biophys Res Commun 523(1): 135-139, 2020. PMID: 31839218. DOI: $10.1016 /$ j.bbrc.2019.12.024

28 Strekalova E, Malin D, Weisenhorn EMM, Russell JD, Hoelper D, Jain A, Coon JJ, Lewis PW and Cryns VL: S-adenosylmethionine biosynthesis is a targetable metabolic vulnerability of cancer stem cells. Breast Cancer Res Treat 175(1): 39-50, 2019. PMID: 30712196. DOI: 10.1007/s10549-019-05146-7

29 Kroes AC, Ermens AA, Lindemans J, Schoester M and Abels J: The reduction of intracellular polyamines by sequential inhibition of the synthesis of decarboxylated S-adenosylmethionine: effects 
on rat leukemia. Cancer Lett 41(3): 295-305, 1988. PMID: 3409208. DOI: 10.1016/0304-3835(88)90291-1

30 Kroes AC, Lindemans J and Abels J: Synergistic growth inhibiting effect of nitrous oxide and cycloleucine in experimental rat leukaemia. Br J Cancer 50(6): 793-800, 1984. PMID: 6498076. DOI: 10.1038/bjc.1984.258

31 Igarashi K, Kawaguchi K, Murakami T, Miyake K, Kiyuna T, Miyake M, Hiroshima Y, Higuchi T, Oshiro H, Nelson SD, Dry SM, Li Y, Yamamoto N, Hayashi K, Kimura H, Miwa S, Singh SR, Tsuchiya $\mathrm{H}$ and Hoffman RM: Patient-derived orthotopic xenograft models of sarcoma. Cancer Lett 469: 332-339, 2020. PMID: 31639427. DOI: 10.1016/j.canlet.2019.10.028

32 Miwa S, Yamamoto N, Hayashi K, Takeuchi A, Igarashi K and Tsuchiya $\mathrm{H}$ : Therapeutic targets for bone and soft-tissue sarcomas. Int J Mol Sci 20(1): 170, 2019. PMID: 30621224. DOI: $10.3390 /$ ijms 20010170

33 Kawaguchi K, Igarashi K, Miyake K, Kiyuna T, Miyake M, Singh AS, Chmielowski B, Nelson SD, Russell TA, Dry SM, Li Y, Unno M, Singh SR, Eilber FC and Hoffman RM: Patterns of sensitivity to a panel of drugs are highly individualised for undifferentiated/unclassified soft tissue sarcoma (USTS) in patient-derived orthotopic xenograft (PDOX) nude-mouse models. J Drug Target 27(2): 211-216, 2019. PMID: 30024282. DOI: $10.1080 / 1061186 X .2018 .1499748$

34 Kawaguchi K, Igarashi K, Kiyuna T, Miyake K, Miyake M, Murakami T, Chmielowski B, Nelson SD, Russell TA, Dry SM, Li Y, Singh AS, Unno M, Eilber FC and Hoffman RM: Individualized doxorubicin sensitivity testing of undifferentiated soft tissue sarcoma (USTS) in a patient-derived orthotopic xenograft (PDOX) model demonstrates large differences between patients. Cell Cycle 17(5): 627-633, 2018. PMID: 29384032. DOI: 10.1080/15384101.2017.1421876

35 Fletcher CD: Undifferentiated sarcomas: what to do? And does it matter? A surgical pathology perspective. Ultrastruct Pathol 32(2): 31-36, 2008. PMID: 18446665. DOI: 10.1080/0191312 0801896945

36 Higuchi T, Miyake K, Oshiro H, Sugisawa N, Yamamoto N, Hayashi K, Kimura H, Miwa S, Igarashi K, Chawla SP, Bouvet M, Singh SR, Tsuchiya H and Hoffman RM: Trabectedin and irinotecan combination regresses a cisplatinum-resistant osteosarcoma in a patient-derived orthotopic xenograft nudemouse model. Biochem Biophys Res Commun 513(2): 326-331, 2019. PMID: 30955860. DOI: 10.1016/j.bbrc.2019.03.191

37 Higuchi T, Sugisawa N, Yamamoto J, Oshiro H, Han Q, Yamamoto N, Hayashi K, Kimura H, Miwa S, Igarashi K, Tan Y, Kuchipudi S, Bouvet M, Singh SR, Tsuchiya H and Hoffman RM: The combination of oral-recombinant methioninase and azacitidine arrests a chemotherapy-resistant osteosarcoma patient-derived orthotopic xenograft mouse model. Cancer Chemother Pharmacol 85(2): 285-291, 2020. PMID: 31705268. DOI: 10.1007/s00280019-03986-0

38 Tan Y, Xu M, Tan X, Tan X, Wang X, Saikawa Y, Nagahama T, Sun X, Lenz M and Hoffman RM: Overexpression and largescale production of recombinant L-methionine-alpha-deaminogamma-mercaptomethane-lyase for novel anticancer therapy. Protein Expr Purif 9(2): 233-245, 1997. PMID: 9056489. DOI: 10.1006/prep.1996.0700

39 Diala ES and Hoffman RM: Hypomethylation of HeLa cell DNA and the absence of 5-methylcytosine in SV40 and adenovirus (type 2) DNA: analysis by HPLC. Biochem Biophys
Res Commun 107(1): 19-26, 1982. PMID: 6289818. DOI: 10.1016/0006-291x(82)91663-1

40 Kulis $\mathrm{M}$ and Esteller M: DNA methylation and cancer. Adv Genet 70: 27-56, 2010. PMID: 20920744. DOI: 10.1016/B9780-12-380866-0.60002-2

41 Cataldo VD, Cortes J and Quintas-Cardama A: Azacitidine for the treatment of myelodysplastic syndrome. Expert Rev Anticancer Ther 9(7): 875-884, 2009. PMID: 19589026. DOI: 10.1586/era.09.61

42 Han Q, Tan Y and Hoffman RM: Oral dosing of recombinant methioninase is associated with a 70\% drop in PSA in a patient with bone-metastatic prostate cancer and 50\% reduction in circulating methionine in a high-stage ovarian cancer patient. Anticancer Res 40: 2813-2819, 2020. PMID: 32366428. DOI: 10.21873/anticanres. 14254

$43 \mathrm{Lu}$ WC, Saha A, Yan W, Garrison K, Lamb C, Pandey R, Irani S, Lodi A, Lu X, Tiziani S, Zhang YJ, Georgiou G, DiGiovanni J and Stone E: Enzyme-mediated depletion of serum 1-Met abrogates prostate cancer growth via multiple mechanisms without evidence of systemic toxicity. Proc Natl Acad Sci USA 117(23): 1300013011, 2020. PMID: 32434918. DOI: 10.1073/pnas.1917362117

44 Yang Z, Wang J, Lu Q, Xu J, Kobayashi Y, Takakura T, Takimoto A, Yoshioka T, Lian C, Chen C, Zhang D, Zhang Y, Li S, Sun X, Tan Y, Yagi S, Frenkel EP and Hoffman RM: PEGylation confers greatly extended half-life and attenuated immunogenicity to recombinant methioninase in primates. Cancer Res 64(18): 6673-6678, 2004. PMID: 15374983. DOI: 10.1158/0008-5472.CAN-04-1822

45 Wang Z, Yip LY, Lee JHJ, Wu Z, Chew HY, Chong PKW, Teo CC, Ang HY, Peh KLE, Yuan J, Ma S, Choo LSK, Basri N, Jiang X, Yu Q, Hillmer AM, Lim WT, Lim TKH, Takano A, Tan EH, Tan DSW, Ho YS, Lim B and Tam WL: Methionine is a metabolic dependency of tumor-initiating cells. Nat Med 25(5): 825-37, 2019. PMID: 31061538. DOI: 10.1038/s41591-019-0423-5

46 Gao X, Sanderson SM, Dai Z, Reid MA, Cooper DE, Lu M, Lu M, Richie JP Jr, Ciccarella A, Calcagnotto A, Mikhael PG, Mentch SJ, Liu J, Ables G, Kirsch DG, Hsu DS, Nichenametla SN and Locasale JW: Dietary methionine influences therapy in mouse cancer models and alters human metabolism. Nature 572(7769): 397-401, 2019. PMID: 31367041. DOI: 10.1038/s41586-019-1437-3

47 Hoshiya Y, Guo H, Kubota T, Inada T, Asanuma F, Yamada Y, Koh J, Kitajima $M$ and Hoffman RM: Human tumors are methionine dependent in vivo. Anticancer Res 15(3): 717-718, 1995. PMID: 7645948.

48 Hoshiya Y, Kubota T, Matsuzaki SW, Kitajima M and Hoffman RM: Methionine starvation modulates the efficacy of cisplatin on human breast cancer in nude mice. Anticancer Res 16(6B): 3515-3517, 1996. PMID: 9042214.

49 Hoshiya Y, Kubota T, Inada T, Kitajima M and Hoffman RM: Methionine-depletion modulates the efficacy of 5-fluorouracil in human gastric cancer in nude mice. Anticancer Res 17(6D): 4371-4375, 1997. PMID: 9494535.

50 Jacobsen SJ, Hoffman RM: and Erbe RW: Regulation of methionine adenosyltransferase in normal diploid and simian virus 40-transformed human fibroblasts. J Natl Cancer Inst 65(6): 1237-1244, 1980. PMID: 6253712.

51 Chen CC, Li B, Millman SE, Chen C, Li X, Morris JP $4^{\text {th }}$, Mayle A, Ho YJ, Loizou E, Liu H, Qin W, Shah H, Violante S, Cross JR, Lowe SW and Zhang L: Vitamin B6 addiction in acute 
myeloid leukemia. Cancer Cell 37(1): 71-84.e7, 2020. PMID: 31935373. DOI: 10.1016/j.ccell.2019.12.002

52 Stern PH and Hoffman RM: Enhanced in vitro selective toxicity of chemotheraputic agents for human cancer cells based on a metabolic defect. J Natl Cancer Inst 76(4): 629-639, 1986. PMID: 3457200. DOI: 10.1093/jnci/76.4.629

53 Sugisawa N, Yamamoto J, Han Q, Tan Y, Tashiro Y, Nishino H, Inubushi S, Hamada $\mathrm{K}$, Kawaguchi $\mathrm{K}$, Unno M, Bouvet $\mathrm{M}$ and Hoffman RM: Triple-methyl blockade with recombinant methioninase, cycloleucine, and azacitidine arrests a pancreatic cancer patient-derived orthotopic xenograft model. Pancreas 50(1): 93-98, 2021. PMID: 33370029. DOI: 10.1097/MPA.0000000 000001709

54 Yamamoto J, Han Q, Inubushi S, Sugisawa N, Hamada K, Nishino H, Miyake K, Kumamoto T, Matsuyama R, Bouvet M, Endo I and Hoffman RM: Histone methylation status of $\mathrm{H} 3 \mathrm{~K} 4 \mathrm{me} 3$ and $\mathrm{H} 3 \mathrm{~K} 9 \mathrm{me} 3$ under methionine restriction is unstable in methionine-addicted cancer cells, but stable in normal cells. Biochem Biophys Res Commun 533(4): 10341038, 2020. PMID: 33019978. DOI: 10.1016/j.bbrc.2020.09.108

55 Yamamoto J, Inubushi S, Han Q, Tashiro Y, Sun Y, Sugisawa N, Hamada K, Nishino H, Aoki Y, Miyake K, Matsuyama R, Bouvet M, Endo I and Hoffman RM: Cancer-specific overmethylation of histone $\mathrm{H} 3$ lysines is necessary for methionine addiction and malignancy. bioRxiv, 2020. DOI: $10.1101 / 2020.12 .04 .412437$
56 Marchetto A, Ohmura S, Orth MF, Knott MML, Colombo MV, Arrigoni C, Bardinet V, Saucier D, Wehweck FS, Li J, Stein S, Gerke JS, Baldauf MC, Musa J, Dallmayer M, Romero-Pérez L, Hölting TLB, Amatruda JF, Cossarizza A, Henssen AG, Kirchner T, Moretti M, Cidre-Aranaz F, Sannino G and Grünewald TGP: Oncogenic hijacking of a developmental transcription factor evokes vulnerability toward oxidative stress in Ewing sarcoma. Nat Commun 11(1): 2423, 2020. PMID: 32415069. DOI: 10.1038/s41467-020-16244-2

57 Kalev P, Hyer ML, Gross S, Konteatis Z, Chen CC, Fletcher M, Lein M, Aguado-Fraile E, Frank V, Barnett A, Mandley E, Goldford J, Chen Y, Sellers K, Hayes S, Lizotte K, Quang P, Tuncay Y, Clasquin M, Peters R, Weier J, Simone E, Murtie J, Liu W, Nagaraja R, Dang L, Sui Z, Biller SA, Travins J, Marks KM and Marjon K: MAT2A inhibition blocks the growth of MTAP-deleted cancer cells by reducing PRMT5-dependent mRNA splicing and inducing DNA damage. Cancer Cell S1535-6108(20)30658-9, 2021. PMID: 33450196. DOI: 10.1016/j.ccell.2020.12.010 [Epub ahead of print].

58 Lauinger L and Kaiser P: Sensing and signaling of methionine metabolism. Metabolites 11(2): 83, 2021. DOI: 10.3390/ metabo11020083

Received August 16, 2020

Revised December 31, 2020

Accepted January 19, 2021 